\title{
O desenho da interpretação e o círculo do sentido
}

\section{Renato Nésio Suttana ${ }^{1}$}

Resumo: A hermenêutica literária do século XX inaugurou a prática da análise (exercitada desde o formalismo russo e amplamente praticada pelo estruturalismo) como tentativa de transpor em interpretação um sentido que nunca está dado totalmente no objeto - a obra literária - para o qual se volta. Neste ensaio são investigadas as relações entre sentido e interpretação, com vistas a mostrar que, toda vez que se tenta converter o sentido em análise, esse sentido de certo modo se degrada, transformando-se numa interpretação, que, ao mesmo tempo em que se volta para o objeto, lhe dá também as costas, no eterno movimento que tem sido o da crítica.

Palavras-chave: Crítica literária. Sentido. Interpretação.

\begin{abstract}
The literary hermeneutics of the 2oth century has inaugurated the practice of analysis (exercised by the Russian formalism and widely practiced by the Structuralism) as an attempt to transpose into the interpretation a sense that is never totally given to the object it examines - the literary work. In this essay, it is investigated the relationship between sense and interpretation, with the objective of demonstrating that, every time one tries to convert sense into analysis, this sense, in a certain way, is degraded, transforming itself into an interpretation which, at the same time that it turns to the object, it also turns against it, in the eternal movement that has been the one of criticism.
\end{abstract}

Keywords: Literary criticism. Sense. Interpretation.

Resumen: La hermenéutica literaria del siglo XX inauguró la práctica del análisis (ejercida por los formalistas rusos y ampliamente practicada en el Estructuralismo) como un intento de transponer para la interpretación un sentido que nunca es totalmente claro en el objeto que se examina - el trabajo literario. En este ensayo, se investiga la relación entre sentido e interpretación, con el objetivo de demostrar que siempre que uno intenta convertir el sentido en análisis, este sentido, de cierta manera, se degrada, transformándose en un movimiento de crítica.

Palabras clave: Crítica literaria. Sentido. Interpretación.

1 Doutor em Letras pela UNESP-Assis, Pós-Doutor em Letras pela Universidad de Buenos Aires e Professor Associado da FACALE-UDGD

Este artigo está licenciado sob forma de uma licença Creative Commons Atribuição 4.0 Internacional,

que permite uso irrestrito, distribuição e reprodução em qualquer meio, desde que a publicação

original seja corretamente citada. https://creativecommons.org/licenses/by/4.0/deed.pt BR. 
"Uma folha de papel está presa com quatro tachas a uma prancheta”, escreve M. C. Escher (1994, p. 15) acerca da reprodução para as edições Benedikt Taschen de uma de suas litografias mais conhecidas. "A mão direita está ocupada a desenhar a manga duma camisa", prossegue: "Ela não tem ainda aqui o trabalho acabado, mas, um pouco mais à direita, uma mão esquerda, que sai de dentro da manga, está já desenhada tão pormenorizadamente, que se levanta da superfície e, por sua vez, como se fosse uma parte viva do corpo, desenha a manga donde sai a mão direita.” O comentário parece-nos perfeito, e nada teríamos a lhe acrescentar a não ser a observação de que - em que pese o fino humor com que é alinhavado - tudo ali é desenho igualmente e que, se alguma coisa "se levanta da superfície”, isso só poderá acontecer na imaginação de quem olha. Tanto a folha quanto as tachas e a superfície que as recolhe pertencem a um único todo de superfície desenhada, o qual proíbe, até certo ponto, estabelecer distinções entre o ato solidário de cada mão de $\neg$ levantar-se e $\neg$ desenhar a outra e a ideia de que ainda falta o que quer que seja para ser desenhado. Para que uma parte seja compreendida como pertencendo ao domínio da natureza - as mãos que desenham - e a outra ao domínio da arte as mangas apenas esboçadas - é preciso que a imaginação aceite tomar parte do jogo, interpretar as áreas sombreadas das mãos como emanações da natureza e os contornos grossos das mangas como esboços de uma arte ainda em construção, arte que provavelmente conduzirá ao naturalismo das mãos que desenham. Mas que diferença mais substancial pode existir entre as mangas inacabadas, mas perfeitamente visíveis e a massa de cinzas e brancos que compõem as mãos, a não ser o fato de que esses cinzas e brancos do esfumado se ajuntaram ali para formar imagens - os dedos, as unhas, as veias do dorso - que identificamos mais facilmente como tais?

Não queremos incorrer aqui no erro, apontado por Blanchot (1997, p. 112), do crítico que, ao comentar um poema de Hölderlin, preocupava-se "em arruinar seu ensaio desde o início, lembrando que um poema é um todo e que os conteúdos de pensamentos retirados desse todo não têm em si mesmos nenhuma validade". De fato, se nos abstemos de fazer interrogações mais profundas, não é tanto pelo temor de que venham a se esvaziar em seguida, na transposição em linguagem da crítica 
daquilo que é exterior a ela de alguma maneira, mas pelo receio de perder contato com o que o pintor ou o poeta nos convidam a ver e a que não teríamos acesso senão pelo mergulho direto nas vertigens da imaginação. Sabemos que os quadros de Escher nos põem frequentemente diante desses impasses. E sabemos também que, se nos desviamos deles com um sorriso desconfiado (como se disséssemos: "Sim, mas na realidade do mundo objetivo as coisas não se passam desse modo)", isso não nos isenta do incômodo. A pintura de Escher - arricar-nos-íamos a dizer não contém apenas esse quê de absurdo ou de curiosidade ocasional que retém por um instante o olhar perplexo do observador, mas é ela mesma a realização concreta (se se pudesse falar assim) dessa perplexidade, a sua concretização em formas que o claro-escuro acinzentado das gravações dá a ver. Portanto, não seria incorreto supor que esses quadros - sejam as divisões regulares de superfícies, sejam os desenvolvimentos de formas e contrastes, sejam aqueles que se detêm nos conflitos entre a superfície e o espaço (como a famosa "Galeria de arte", em que um mesmo observador vê o quadro e pertence ao mundo que o quadro retrata) ou as “construções impossíveis" (ESCHER, 1994, p. 16), como "Belvedere”, "Escada acima e escada abaixo" ou "Queda d'água”, na classificação do autor -, mais do que lançarem uma vista de olhos irônica em direção ao mundo e às regras da perspectiva que tentam apreendê-lo na tela, são eles mesmos ou incorporam em si aquilo que querem dizer. Por outros termos, qualquer que seja o conteúdo metafórico a atribuir a essa pintura, tal conteúdo se dissolve nela como parte dela: ela é, sem nenhuma transição visível (como poderia acontecer, por exemplo, nas pinturas de teor narrativo, em que a realidade e o que se diz da realidade se separam com certa nitidez), aquilo que ela diz e o ato de dizê-lo enquanto o diz.

Com efeito, numa situação que escapa ao domínio da pintura, mas que tem a ver com ele, uma vez que nos remete imediatamente ao universo vertiginoso da interpretação e do sentido, Blanchot (1997, p. 187) observou, falando de Sartre, a propósito dos chamados romances de tese, que, se "não há arte literária que, direta ou indiretamente, não queira afirmar ou provar uma verdade", o conteúdo dessa verdade, qualquer que seja ele, estará sempre comprometido com esta característica da obra de ficção, que é, surpreendentemente, o fato de que ela "nada tem a ver com honestidade: ela trapaceia e só existe trapaceando”. Porém, isso não significa 
que a obra se desvie da verdade ou que não possa ter qualquer pretensão a ela. Igualmente, na opinião de Blanchot, se a obra "tem parte, em todo leitor, com a mentira, o equívoco, um eterno movimento de engodo e de esconde-esconde" e sua “sua realidade é o deslizamento entre o que é e o que não é”, sendo a sua verdade "um pacto com a ilusão", e se ela "mostra e retira; vai a algum lugar e deixa crer que o ignora", o movimento que vai de um extremo ao outro a consome inteiramente, mas é também o seu instante de maior abertura para o real. Ainda nas palavras do crítico, "é no modo imaginário que [a obra] encontra o real, é pela ficção que se aproxima da verdade", ou seja:

Ausência e eterno disfarce, ela progride por caminhos oblíquos, e a evidência que lhe é própria tem a duplicidade da luz. O romance é uma obra de má-fé, má-fé de parte do romancista, que crê em seus personagens e, no entanto, se vê por trás deles, que os ignora e os realiza como desconhecidos e encontra na linguagem, da qual é senhor, a maneira de dispor deles sem deixar de crer que lhe escapam. Má-fé do leitor, que brinca com a imaginação, que brinca de ser o herói que ele não é, de tomar como real o que é ficção, e que finalmente se deixa enganar e, nesse encantamento, se deixa a existência de lado, reencontra uma possibilidade de viver o sentido dessa existência (BLANCHOT, 1997, p. 187).

As observações de Blanchot parecem irretorquíveis neste ponto. No entanto, ainda poderíamos perguntar-nos pelo modo como a obra consumindo na irrealidade todo o seu poder de alcançar a realidade e, ao mesmo tempo, ao consumi-lo, reconquistando-o naquilo que é nãoser, mas o não-ser do qual o ser não prescinde para se afirmar como tal (paradoxo que é próprio da oscilação em que a obra se encontra entre o real e o irreal de sua afirmação) - torna-se ela mesma um objeto passível de perscrutação e de sentido. Pode a obra justificar, nesse movimento fantasmal, a sua entrada em nossas vidas (injustificáveis), e por que, sendo tudo como é, precisamos dela para afirmar uma realidade ou uma presença de ser que, fora dela, não é senão a nossa 
própria existência configurada como tal? Num ensaio sobre Kafka, Blanchot dirá que o poder de objetivar da obra (um termo que vai buscar a uma frase do autor tcheco: "Nunca pude compreender que seja possível a alguém que queira escrever objetivar a dor na dor") confina com o seu poder de desfazer a objetividade. Para Blanchot, "a palavra objetivar chama a atenção, porque a literatura tende justamente a construir um objeto. Ela objetiva a dor constituindo-a em objeto" (1997, p. 27). As reflexões são instrutivas aqui. Se a obra, ao objetivar a dor (ou, diríamos, ao objetivar qualquer aspecto do real), a objetiva constituindo-a em objeto, isso ocorre porque ela "não a expressa", mas "a faz existir de um outro modo", isto é, lhe dá "uma materialidade que não é a do corpo, mas a materialidade das palavras pelas quais é significado o transtorno do mundo que a dor pretende ser". Entramos então no terreno do que poderíamos pensar ser a obra em si, consumida em seu movimento de doar e recolher - o qual se representa, no âmbito da pintura, na obra de Escher pelo fato de que essa obra dissipa toda intenção de representação em sua interioridade única, tornando-se ela mesma aquilo que representa e aquilo que é representado, a idéia e a expressão da idéia num único todo inextricável. Ainda sobre Kafka, Blanchot (p. 27) escreve:

Tal objeto não é necessariamente uma imitação das transformações que a dor nos faz vivenciar: ele se constitui para apresentar a dor, não para representá-la; é preciso primeiro que este objeto exista, isto é, que ele seja um total sempre indeterminado de relações determinadas, em suma, que haja nele, como em todas as coisas existentes, sempre um algo mais que não seja verificável.

À famosa queixa de Kafka de que, para escrever uma história, não tinha tempo de se "estender em todas as direções, como seria preciso", 
Blanchot responde, pois, com a noção de que essa queixa "indica a natureza da expressão literária: ela irradia em todas as direções e indica também o caráter do movimento próprio a toda criação literária”. Ou, em outros termos e com referência mais precisa ao drama de Kafka: "só a tornamos verdadeira buscando-a em todas as direções, perseguidos por ela, mas ultrapassando-a, empurrados por todos os lados e atraindo-a por todos os lados" (p. 27). Assim, o "Eu sou infeliz" que o escritor pronuncia é, nas palavras do crítico, "infelicidade somente espessando-se nesse novo mundo da linguagem onde toma forma, mergulha, se perde, se obscurece e se perpetua". A obra, no movimento que converte o real em irrealidade e, ao mesmo tempo, afirma como realidade o que é irreal (movimento do qual a expressão da dor seria a manifestação mais sincera, uma vez que não se pode falsear nem trocar por um substituto que o transformasse em qualquer coisa mais suscetível de aceitação para o autor e para o leitor, embora a este último possam escapar certos lances mais dramáticos da criação da obra que são próprios da experiência do autor), é esse espessamento que no entanto é vazio e destituído de consistência: como se o afirmar ali negasse toda afirmação. Pode a interpretação, em seu campo específico (seja ele qual for), avançar em meio a esse espessamento sem perder, ela também, o seu poder de afirmar? Ou, como supôs o comentarista de Hölderlin, a obra lhe escapa de tal maneira que o comentário, julgando estar ainda na intimidade da obra, nada mais faz do que girar no vazio, na ilusão de apreender o que já lhe escapou desde o começo?

Uma pergunta que se poderia fazer (mas cujo sentido talvez não nos fosse totalmente perceptível por agora) seria aquela acerca do que a crítica procura nas obras. É preciso admitir que a concepção da obra 
literária como uma totalidade que objetiva ao mesmo tempo em que se priva de toda objetividade (que talvez remonte ao conceito aristotélico da mimese entendida como uma relação imperfeita com o real sensível) não esclarece a posição do comentário diante do objeto, embora a implique de algum modo. Fechada em si, "nesse novo mundo da linguagem" onde a realidade do mundo "toma forma, mergulha, se perde, se obscurece e se perpetua”, a obra parece suscitar imediatamente um fato de comunicação que faz nascer o comentário. Quanto a isso, ao falar da interpretação que Heidegger dá dos poemas de Hölderlin, Blanchot reconhece que há uma certa disparidade, uma certa distância a separar a obra e o comentário, mas que há também, nessa distância, uma profunda intimidade, como se a vida da obra se realizasse mais plenamente no comentário, embora este pareça descolar-se dela e adquirir uma vida própria: "Não devemos, pois, temer que o comentário acrescente ao texto. O que ele lhe empresta podemos dizer que o tomou emprestado" (BLANCHOT, 1997, p. 114). Talvez fosse preciso reconhecer que o comentário não pode existir senão nessa relação de dependência frente à obra, que tanto lhe proíbe adquirir uma legitimidade própria quanto lhe concede legitimidade, desde que “o que ele empresta” à obra se pode dizer "que o tomou emprestado". Para Blanchot, há que reconhecer que o comentário, muitas vezes, faz florescer aquilo que nas obras está apenas em latência ou se manifesta nelas como uma espécie de privação cujo poder de se expandir advém do próprio fato de que se encontre aprisionado:

Eis outra observação que gostaríamos de fazer, no plano das correspondências entre a linguagem que interpreta e a linguagem objeto de interpretação: sabemos que a língua de Hölderlin é em aparência pobre, pobre de palavras, pobre de 
temas, monótona, a mais humilde, a mais elevada que já se escreveu, pois seu movimento se eleva acima de todas as outras" (p. 114).

A linguagem do comentário, porém, é de uma outra espessura, que contrasta com o que Blanchot supõe ser a linguagem do objeto para o qual o comentário se volta:

Mas a linguagem de Heidegger é, ao contrário, de uma riqueza e de uma virtuosidade incomparáveis [...], e mais do que nunca, ao que parece, ele é tentado pelos recursos infinitamente ricos da língua alemã, esse perigoso poder que as palavras extraem do jogo de suas estruturas, das inflexões de sentidos provocadas pela dança incansável dos prefixos e sufixos em torno de um corpo verbal etimologicamente transparente. A confiança que Heidegger tem nas palavras de sua língua, o valor que dá às suas parecenças mais ou menos secretas, constituem um fenômeno notável. As palavras parecem carregar em si próprias uma verdade oculta que uma interrogação bem conduzida poderia fazer aparecer (BLANCHOT, 1997, p. 114-115).

É pena que o próprio Blanchot não se tenha encarregado dessa investigação, pois, após intuir-lhe a necessidade, logo a abandona para seguir o seu caminho particular. A "pobreza” de Hölderlin será o ponto de partida para um outro empreendimento, que se desembaraça da tarefa de investigar a legitimidade do comentário e abraça o esforço de produzir um comentário próprio, que, de qualquer maneira, não pode partir senão da ideia de que existe o que quer que seja para ser comentado:

Os temas de Hölderlin são pobres. Mas, não tendo o poema outro objeto senão ele próprio, a poesia, mais fortemente que em qualquer outra parte, ali é real e verdadeira, verdade que lhe dá o direito de dispor de todo o resto e primeiramente de tudo" (BLANCHOT, 1997, p. 115). 
A quem se dirige o crítico afinal? A si mesmo, ao afirmar, com admirável confiança (essa confiança sem a qual nenhuma crítica parece ser possível), que "a poesia [...] ali é real e verdadeira" e que essa verdade "lhe dá o direito de dispor de todo o resto e primeiramente de tudo"? Ou a algum ouvinte que, incerto ainda dessa verdade que no poema se afirma como tal, carece da afirmação do crítico para se avizinhar de "uma existência poética tão forte" e, na certeza dessa afirmação, admitir que "o poeta é o mediador, ele faz a ligação entre o próximo e o longínquo" - o ponto de partida, portanto, para um comentário que procura o seu próprio caminho e a sua própria coerência? Ouçamos outra vez as palavras do crítico:

Quando queremos encontrar o que pode significar o fato de que o poema, de que o canto existe, e se pretendemos interrogar esse fato do exterior, essa interrogação deve conduzir a Hölderlin, porque, para ele mesmo e do interior, essa interrogação faz nascer o poema. Interrogar Hölderlin é interrogar uma existência poética tão forte que, uma vez sua essência desvendada, ela mesma se pôde provar impossibilidade e se prolongar no nada e no vazio, sem cessar de se realizar (BLANCHOT, 1997, p. 115).

Qualquer que seja o caminho (que nos dispensaremos aqui de trilhar) a ser seguido, as observações de Blanchot trazem à luz o fato de que os argumentos corriqueiros de que a crítica "ilumina" as obras criticadas ou de que ajuda na sua "compreensão" (qualquer que seja ela) serão sempre insuficientes diante da constatação de que a crítica (ou o comentário) precisa pleitear a sua própria coerência. Não nos detenhamos por muito tempo no ponto. Admitamos apenas que, no pensamento de Blanchot, a distância entre a obra e o comentário parece estar elidida, embora isso não ocorra realmente, até porque não 
há como admitir que o comentário não exista senão a partir do momento em que se reconhece tal distância. Mas que tipo de existência é essa que, ao mesmo tempo em que se assume como uma espécie de derivação do seu objeto de estudo, se reconhece também como uma diferença essencial em relação a ele, a tal ponto que, nas críticas de teor positivista, se chegue a conceber para ele (o objeto) uma existência completamente independente? Os meios-termos - a noção de que o comentário é ele mesmo e alguma coisa que está fora dele, mas para a qual se volta como se para uma exterioridade inteiramente reconhecível - não nos satisfariam por agora, conquanto também não possamos dispensar os paradoxos. Porém não podemos avançar senão reconhecendo que ali onde a distância silencia ela se manifesta mais plenamente, ela se mostra como uma necessidade do pensamento sem a qual o próprio pensamento não pode passar. Podemos dar a ela um sentido, uma significação que não dependa só da negatividade da recusa que ela implica - o afastamento que permite concluir que nenhuma crítica tem objeto, desde que o objeto, falante por si mesmo, dispensa uma voz de crítica que o ajude a dizer aquilo que somente ele é capaz de dizer (segundo o juízo do comentarista de Hölderlin mencionado por Blanchot) -, mas que faz aparecer a crítica como uma realidade do sentido, tão legítima quanto é legítimo o objeto cuja legitimidade tem sido a sua missão resguardar?

Houve um tempo em que se usou, talvez com um excesso de otimismo de que hoje é justificável desconfiar, empregar a expressão "ciência da literatura" para demarcar essa distância, para lhe dar um sentido que a crítica que não recusa o paradoxo não costuma admitir. Pontos de partida como este, de Wolfgang Kayser - que até há algum tempo nos pareceriam claros e funcionais, mas que hoje nos soam 
obscuros, insuficientes para estabelecer as balizas que, a seu tempo, serviram para sustentar todo um arcabouço de lucubrações - teriam por meta transformar em positividade o que na distância era negação: "A ciência da literatura parece indicar o seu próprio objecto com a expressão: literatura. Mas o que quer dizer 'literatura'?" (KAYSER, 1985, p. 4). A trajetória que neles se abre parece nítida, remetendo-nos com certa reserva àquele ponto do sentido onde a literatura, afirmação do real em sua própria negação, não pode ser outra coisa que uma evidência domesticada: “'Passou o outono já, já torna o frio’ - estas duas frases, por exemplo, poderíamos imaginá-las como parte de uma conversa banal, entre duas pessoas que falam da época do ano e do tempo. Os significados referem-se neste caso a realidades existentes independentemente de quem fala" (KAYSER, 1985, p. 6). Evocar a presença de "realidades existentes" estabelece as bases para um raciocínio que salva não tanto o poema de naufragar na distância, mas a crítica de perder contato com o seu próprio território de manobras: "Se, porém, lermos esta linha no ponto em que está inserta, isto é, como primeiro verso de um soneto de Camilo Pessanha, deveremos interpretá-la por forma totalmente diversa, sob pena de lhe falsearmos o sentido" (p. 6). E como se pode falsear o sentido, quando esse sentido não está dado senão como um pressuposto, como uma pressuposição da qual o crítico não se dá conta e sem a qual, no entanto, não pode conceber sequer a possibilidade do falseamento? O sentido depende, porém, de um recuo que o recorta como totalidade, como possibilidade de um dizer que é o seu começo e a sua verdade:

Aqui os significados das palavras já não se referem a factos reais. Pelo contrário, os factos aqui adquirem qualquer coisa 
de estranhamente irreal, pelo menos uma existência peculiar, absolutamente diversa da realidade. Os factos ou, como também diremos, a objectualidade [...], existem somente como realidade evocada por estas frases poéticas. As frases do poema têm a capacidade de provocar a sua própria objectualidade. Acerca da realidade do outono do ano de tal e tal é-nos lícito fazer observações inúmeras. A objectualidade naquele verso é constituída pelas frases que a produzem e a ligação neste caso é tão estreita, que o mundo do poema seria totalmente diverso se alterássemos a mínima coisa na linguagem, por exemplo, as inversões [...], a repetição do "já”, a pausa, o ritmo, o som, o comprimento do verso (KAYSER, 1985, p. 6).

Que as observações do crítico se concluam com pormenores de ordem gramatical indica que, para Kayser também, tal como para Heidegger, a fidelidade ao dito é garantia de fidelidade ao sentido. Igualmente, a noção de que o poema suspende a objetualidade do mundo ou provoca a sua própria objetualidade (que, no entanto, há de ser sempre de algum modo paralela a do mundo remete-nos para aquele nó do sentido, no qual a própria afirmação que a crítica faz a respeito do poema e do real que o poema indigita se coloca em questão. No entanto, é o fato mesmo de que concebamos as coisas dessa maneira que permite, para nos mantermos fiéis às ideias de Kayser, habitar o lado de cá desse dizer vertiginoso, capaz de se afastar do real sem, no entanto, perder o fio da meada, como se do afastamento é que tirasse a sua capacidade de afirmação. De certo modo, há que conceber, nesse fio de raciocínio, que, se a obra literária provoca uma objetualidade própria que só se recupera na medida em que mantém certo contato com a objetualidade do mundo, a crítica, no entanto, fundada numa outra categoria do dizer, diz efetivamente alguma coisa do real, ou seja, não cria uma objetualidade própria (como o faria o poema), porque o objeto para o qual se volta - poema, romance, conto ou outro - estará 
sempre lá, à espera, como presença que responde, seja como for, à pergunta pelo que quer dizer "literatura" com a qual o crítico inicia a sua caminhada. É legítimo esse procedimento? Seria razoável interrogálo mais de perto, procurando averiguar em que medida o que se propõe como resposta não é senão um modo de contornar a vertigem, que toma como resposta uma forma qualquer da pergunta que apenas se repete indefinidamente.

Por outros termos, essa maneira de conceber a "ciência da literatura" como domínio de um saber cuja verdade só se pronuncia fora da literatura, ou melhor, do objeto literatura que tenta instituir como direção desse saber, implica também assumir que, a cada vez que essa verdade é enunciada, qualquer coisa de uma mentira se mistura a ela, minando-a por dentro e condenando a crítica a um eterno recomeço. Pensemos em todo o volume de comentário que se pode produzir sobre um escritor e em toda uma verdadeira tradição de saber acadêmico sobre a literatura que se formou, por exemplo, no Brasil a partir da segunda metade do século XX, em que a exigência de se produzir uma crítica que se mantivesse sempre fiel ao rigor de suas premissas (impondo-se, portanto, a convocação ao rigor como palavra de ordem que franquearia, de uma vez para sempre, o acesso a um saber cujos estatutos, até então, conforme se acreditava, por razões de ordem metodológica, não tinham sido estabelecidos claramente) pareceu firmar-se, num certo setor da produção acadêmica, como um verdadeiro axioma. Já nos anos cinquenta, quando ainda dava os seus primeiros passos como ideário de toda uma geração de críticos que logo floresceria, Adolfo Casais Monteiro (1961, p. 164) ironizou-a, ao falar da estilística, acusando-a de reduzir a obra literária a uma "poeira atômica, 
na qual já não era possível divisar qualquer objeto", dada exatamente à sua equívoca pretensão de objetividade. Mas é este ponto mesmo que merece nossa atenção. Divisamos nele qualquer coisa de um esquecimento (como se a crítica, ao tentar começar de uma base absolutamente inédita e de limpada dos hibridismos que o formalismo russo imputou às formulações das poéticas e da estética que o antecederam, não pudesse lembrar-se de que o saber no qual instalava a sua tenda era o saber de todos os tempos, manifesto numa tradição de estudo da literatura da qual não se podia alijar pelo simples gesto de arrogar para si mesmo uma base metodológica mais "consistente") esquecimento que, no entanto, fundaria toda uma tradição de crítica e comentário.

A seu tempo, num torneio de raciocínio que lembraria o de Kayser, Wellek e Warren, em sua Teoria da literatura, escreveriam que o objeto de estudo da crítica poderia ser recortado partindo-se de certas qualidades de sua linguagem. Algumas distinções se fariam oportunas, como aquela que separa a linguagem cotidiana da científica e ambas, por sua vez, da literária. Para Wellek e Warren (1962, p. 30) certa relação da linguagem literária com a realidade poderia servir como ponto de partida para a distinção, manifestando-se nesta "uma espécie de enquadramento que coloca fora do mundo da realidade a afirmação contida na obra”, o que permitiria reintroduzir, na análise, algumas das concepções comuns da estética: 'contemplação desinteressada', 'distância estética', 'enquadrar”'. Sendo fluida, porém, a distinção entre arte e não arte - noção que se toma como um a priori da interpretação, mas que nos aparece hoje muito mais como um corolário de tal maneira de raciocinar -, se afiguraria melhor "considerar apenas como literatura as obras nas quais é dominante a função estética”, aquelas em 
que o distanciamento do real permite pensar na sua natureza como numa natureza distinta, em que o ato de dizer está como que suspenso, devido a uma qualidade desse dizer que o torna único no universo da linguagem:

\begin{abstract}
Mas é no aspecto da "referência" que a natureza da literatura transparece mais claramente. $\mathrm{O}$ cerne da arte literária encontrar-se-á, obviamente, nos gêneros tradicionais: lírico, épico, dramático. Em todos eles existe uma "referência", um relacionar com um mundo de ficção, de imaginação. As afirmações contidas num romance, num poema ou num drama não representam a verdade literal; não são proposições lógicas. Existe uma diferença central e importante entre uma afirmação, mesmo a produzida num romance histórico ou num romance de Balzac que pareça comunicar uma "informação" acerca de sucessos reais, e a mesma informação quando publicada num livro de história e de sociologia (WELLEK e WARREN, 1962, p. 31).
\end{abstract}

A qualidade dessa afirmação depende, pois, de ser ela uma afirmação de segundo nível, que não dá o fato como tal na luz mais crua da experiência imediata, mas que o reescreve segundo uma linguagem de ficção ou de imaginação que é necessário perquirir. Mas o mais espantoso é que essa crítica, reconhecendo tal qualidade da linguagem literária (que hoje nos pareceria verdadeiramente abissal), se acredite em condições de se lançar a ela de olhos abertos e espírito lúcido - num ato de confiança inaudita, da qual porém são provas os livros de Kayser e de Wellek e Warren (uma teoria que esquadrinha todos os setores da atividade literária, na esperança de que, assim fazendo, todo o vasto campo de seu objeto poderia ser, senão percorrido, pelo menos mapeado para aprofundamentos futuros, a cargo quem sabe de produções monográficas que o desdobrariam indefinidamente). Conceber a linguagem da literatura como um 
deslocamento, como um distanciamento que, no entanto, retorna incessantemente sobre o mundo, permite sobretudo perceber o ponto de inflexão a partir do qual a crítica passa a existir como uma atividade voltada para um objeto:

O tempo e o espaço num romance não são o tempo e o espaço reais. Até mesmo o mais aparentemente realista dos romances - por exemplo, as próprias "talhadas de vida" dos naturalistas - não deixa de ser construído de acordo com certas convenções artísticas. Especialmente encarando-os de um ângulo histórico mais recente, apercebemo-nos de como são idênticos entre si os romances naturalistas - pela escolha do tema, pelo tipo de caracterização das personagens, pelos sucessos escolhidos ou admitidos, pelos modos de conduzir o diálogo (WELLEK e WARREN, 1962, p. 31-32).

O ponto de vista de Wellek e Warren lembra, neste aspecto, as formulações do formalismo russo das primeiras décadas do século passado, que também viu na possibilidade do distanciamento as bases para a fundação de uma crítica. No entanto seria necessário falar, quanto ao formalismo, de um duplo distanciamento: aquele que a linguagem da literatura estabelece em relação ao mundo, ao se manifestar (para utilizarmos os termos de Kayser) como linguagem que suspende a objetualidade do real, e um distanciamento mais profundo e talvez mais sutil que é aquele em que a própria linguagem se coloca em relação àquilo que toma como objeto.

É esta última, portanto, que se põe mais imediatamente em questão, uma vez que é a partir dela que o outro distanciamento superado, por assim dizer, o seu caráter abissal, que nos faria recuar do empreendimento de tentar fundar uma crítica que pudesse manter-se lúcida diante da ameaça de fracasso a que a expõe o caráter profundamente negativo do objeto - é percebido como tal e, logo, se 
torna passível de uma teorização. Para os formalistas russos, o sentido da questão, deslocando-se da relação entre obra e realidade, que deixa perplexa uma crítica milenar, se revertia não tanto em direção ao ato de perceber a realidade que funda a obra na perspectiva da mimese aristotélica, mas em direção ao ato de perceber a obra como tal por parte de um leitor que, tomando esse real como ponto de partida, mediria o caráter de distorção da percepção que funda a obra quando comparada com outras obras e o aprofundamento da percepção que essa distorção favorece.

Para Eikhenbaum (1971, p. 14-15), por exemplo, tratava-se de enunciar um procedimento "de singularização" e um procedimento "da forma difícil, que aumenta a dificuldade e a duração da percepção: o procedimento da percepção em arte é um fim em si mesmo e deve ser prolongado". Surpreendente transformação, que converte o caráter abissal de um dizer que só diz o real porque o transforma em irrealidade e mentira num jogo de formas em que esse real jamais se perde, mas se garante mais como presença quanto mais profundo for o sulco, quanto mais longe se levar o procedimento da "singularização" que faz da presença (da palavra e da forma) uma verdade, sem nada ver nisso de espantoso:

A arte vive dessa interação, desse conflito. $O$ fato artístico não existe independentemente da sensação de submissão, de deformação de todos os fatores pelo fator construtivo [...]. Mas, se a sensação de interação dos fatores desaparece (e ela supõe a presença necessária de dois elementos, o subordinante e o subordinado), o fato artístico apaga-se; a arte torna-se automatismo (TYNIANOV, 1971, p. 107).

Hoje em dia, teríamos dificuldade em subscrever tais afirmações. Não é que elas subestimem, com uma autoconfiança quase adolescente, 
as questões realmente cruciais da arte como presença na vida dos homens. Porém, não há como negar que as respostas que comportam contêm um quê de subestimação, como se a fundação de um espaço de crítica, no qual seja possível falar das formas em si, dotadas de um conteúdo que o crítico revista incessantemente, na certeza de sua positividade e de sua idoneidade como palavra do mundo, nos isentasse de afundar nos lodaçais do que é sem palavra e sem verdade e que, por ser assim, só é presença na medida em que se manifesta como um instransponível distanciamento ou uma ausência atordoadora. O formalismo, porém, aceita as regras do seu próprio jogo, aceita esse ficar aquém como garantia de sucesso e assim tem garantida, pelo menos no seu campo, a conversão da crítica em método, em tecnologia de análise cujo horizonte se recupera a cada vez que parte em demanda, no círculo de seus próprios procedimentos: “[...] vê-se que seria por princípio mais correto falar, não sobre um novo método, mas sim, sobre novas tarefas de pesquisa, sobre um novo círculo de problemas científicos" (JIRMUNSKI, 1971, p. 57, grifos do original).

Pode ser que o círculo de problemas diga respeito muito mais ao formalismo, em sua pretensão de avançar com segurança por um terreno firme, do que a qualquer outra coisa que esteja fora dele. Seria justo perguntar-nos pelo tipo de alvo que se pretende atingir ao dispor os argumentos dessa maneira e aonde se quer chegar com a postulação de um método seguro cuja principal virtude seria converter, quando muito, a negatividade e a obscuridade da arte num tipo de positividade que já é, por si mesmo, espantoso o bastante para que o vejamos de outra maneira. Para Vitor Chklovski, a perquirição do modo como, na arte, real e irreal tendem a se confundir se resolve na perquirição dos procedimentos que fazem da arte uma linguagem do real, cujo começo 
é o real e cujo término, desbordando para um desvio que tem por função recuperar mais adiante a realidade de que os usos comuns da linguagem (desgastados pelos automatismos) não podem dar testemunho, é o seu aprofundamento. A arte, convertida em procedimento, leva à conclusão de que todo o "trabalho das escolas poéticas" nada mais seria do que a "acumulação e revelação de novos procedimentos para dispor e elaborar o material verbal" (CHKLOVSKI, 1971, p. 41). Nesse passo, seria preciso aceitar que, para concedermos objetividade ao material artístico ou, melhor, para percebermos a positividade desse dizer desviante que só alcança o real no momento em que o perde, a literatura, seja ela o que for, existe para o crítico como literatura, sendo o seu modo de operar diverso do modo como opera a linguagem comum. Deter-se nos procedimentos de desvio é, assim, abrir a possibilidade de um acesso mais pleno ao objeto, salientando-se no que se chama comumente de "estranhamento" ou "desvio" as diferenças que servem para "reforçar a sensação" produzida pelos objetos (CHKLOVSKI, 1971, p. 42), processo que - ao contrário de conduzir, como seria de esperar, a uma espécie de perda de realidade é intuído pelo crítico como um ganho, como uma conquista de realidade que elide, nessa positividade luminosa das formas franqueada pelas diferenças, os abismos do paradoxo e da estranheza:

Eis que para devolver a sensação de vida, para sentir os objetos, para provar que pedra é pedra, existe o que se chama arte. O objetivo da arte é dar a sensação do objeto como visão e não como reconhecimento; o procedimento da arte é o procedimento da singularização dos objetos e o procedimento que consiste em obscurecer a forma, aumentar a dificuldade e a duração da percepção (CHKLOVSKI, 1971, p. 45). 
Se essa maneira de ver parece insuficiente, no que diz respeito à estranheza do objeto como tal (e não apenas ao que se pensa ser a estranheza de sua linguagem ou de certos aspectos dessa linguagem), nem por isso deixa de ser um modo de a crítica abrir para si um território positivo de manobras. Tomando o sentido que atribui ao objeto como sendo o sentido total da experiência literária (num processo de ascese que, finalmente, ameaçará redundar no esvaziamento da própria linguagem da crítica, conforme se pode suspeitar ao ler certas produções da crítica contemporânea), o formalismo resolve, nem que seja para o seu próprio consumo, a questão da arte como experiência da estranheza e da conquista da realidade (que nunca está garantida no objeto) por meio da irrealidade (ou da irrealidade por meio do que só pode ser a realidade, na concepção de Blanchot), tomando-a como uma experiência adstrita aos limites da simples expressão: a literatura é o que se vê ali, mesmo que o que se vê ali elida qualquer pretensão de teorizar a seu respeito. No formalismo, o problema da crítica - entendida como uma linguagem idônea da experiência do ler que põe à mostra todos os seus mecanismos - se superpõe à pergunta, mais contundente, pela experiência da arte como estranheza e distanciamento (quer dizer, como experiência do sentido em si mesmo, tomado em sua máxima amplitude), resolvendo-se num todo de explicações e formulações de caráter metodológico cujo fundo, enfim, dissimula as dificuldades reais. Ou, para recorrermos às palavras de Chklovski (1971, p. 55), o objetivo da "imagem" em literatura seria não tanto "tornar mais próxima de nossa compreensão a significação que ela traz, mas criar uma percepção particular do objeto, criar uma visão e não o seu reconhecimento". 
Em tempos de especialização e de fragmentação dos saberes em áreas que quanto mais se aprofundam mais parecem distanciar-se umas das outras, a busca de um método, com suas promessas de rigor e de coerência, parece sedutora para os espíritos cansados. A ideia de que a crítica não se faz apenas de julgamentos e de escolhas arbitrárias (orientados por padrões de gosto e de avaliação cujos fundamentos, se interrogados de frente, não poderiam ser explicitados claramente pelos seus próprios entusiastas) suscitou um novo ânimo na crítica, dando a impressão de que finalmente se teria encontrado o caminho. Entretanto, a conversão da literatura em objeto de análises, em objeto de perscrutações que quanto mais a esmiúçam mais parecem perder de vista a totalidade que almejam abarcar, cobra o seu preço, que é não só a suspeita de que se perdeu há muito a esperança de atingir o fundo do que se perscruta, mas de que, no ato de buscar a luz, se comece a caminhar de costas para ela, como se tal cegueira constituísse ela mesma a única promessa de sucesso. Convertendo em análise ou no que quer que seja o estudo da literatura, a crítica, inspirada pelo formalismo, avança em direção ao objeto, aposta no que julga ser a sua presença indubitável e, assim, se ganha e se garante num verdadeiro passe de mágica, embora ao custo de perder o sentido de seu empreendimento. Justificada em seus argumentos, mas esquecida de que esses argumentos só se justificam, por seu turno, na medida em que se fundam num sentido, numa espessura de ser que é origem e direção de toda a trajetória, produz e reproduz interminavelmente uma ilusão cujo horizonte de chegada não pode ser outro que ela mesma e o círculo de seus próprios argumentos: a crítica se converte numa ciência da literatura, em condições, finalmente, de especializar-se em seu setor. 
Nesta altura, enunciar a palavra sentido, em semelhante universo de significações, nos aproxima do ponto a que tudo isso parece conduzir-nos. O que é sentido em literatura senão uma possibilidade, uma generosidade da obra que se abre para a leitura e, franqueando o acesso à sua intimidade, se ilumina com a promessa de que é possível avançar nessa intimidade e aprofundá-la, na esperança de que o saber que promete é um saber verdadeiro, capaz de competir com os saberes do mundo e da ciência? Entretanto, se esse saber não está negado na promessa, nada é ali, ainda, verdadeiro - nada se disse que possa ser uma garantia de verdade, e cada tentativa de aproximação parece frustrar-se no movimento da recusa que não deixa de ser, apesar de tudo, sentido em sua mais plena acepção, mas sentido como promessa e recusa, aproximação e fuga, engajamento e dispersão do ser numa irresponsabilidade triunfante. Não podemos, evidentemente, reduzir a noção de sentido a um conceito ou a um mero dado do raciocínio, porque isso seria de certa maneira degradá-lo, conforme o demonstram as críticas que se lançam à análise das obras a partir de seus materiais e de seus meios. Para termos uma ideia da amplitude da noção, tomemos a seguinte passagem do livro Argumentação contra a morte da arte, de Ferreira Gullar. Ao falar das opções vanguardistas modernas, que em muitos aspectos conduziram a experiência artística a becos-sem-saída que ainda agora solapam as bases de qualquer experiência (e não estamos a falar de uma contemplação no âmbito da antiga estética, mas de uma experiência do sentido que é também comunicação e comunhão dos homens consigo mesmos e com o mundo), Gullar (1993, p. 21) afirmou que "a grande revolução de agora é redescobrir [...] que a arte não é uma dádiva dos deuses mas uma invenção maravilhosa do homem e que sua destruição só nos empobrece a todos" [grifo nosso]. 
Não é essa uma intuição que nos põe a caminho de uma experiência de uma imersão no sentido que, certamente, transcende a confusão usual, presente no universo da crítica, que leva a tomar o que as obras dizem de fato - o seu sentido inalienável, que só pode ser vivenciado individualmente por quem se lança à experiência da leitura ou da contemplação - com o que ela quer ou pode dizer, que alimenta as esperanças do comentário?

$\mathrm{O}$ fato de que se possa dizer que o fim da arte nos empobrece a todos não implica, por certo, que com isso a arte se empobreça, mas que o fenômeno da arte, como uma experiência mais essencial do homem, o põe de frente para opções que não têm a ver somente com um julgamento equilibrado ou com uma interpretação mais justa. Não queremos repetir a noção, algo desgastada, de que a arte é necessária ou de que a presença dela em nossas vidas nos torna melhores ou mais sábios. A intuição de Gullar nos lembra, antes, que, se a ideia de perder a arte nos incomoda, isso ocorre porque ainda não sabemos o suficiente sobre ela, e que essa ignorância (que, por sua vez, não limita com aquele tipo de ignorância que está na origem da ciência) é a contraparte de sua maior riqueza. A experiência do sentido é, então, experiência dessa riqueza - experiência que, evidentemente, não se esgota em nenhuma tentativa de esclarecimento, mas que, por ser assim, nos induz sempre à pretensão paradoxal de esgotá-la. É o que põe em movimento, supomos, as críticas de teor positivista ou analítico, bem como conduz às tentativas de resposta que se sucedem ao longo das épocas, que não sabemos se derivam do modo como se vive a arte no seio do mundo ou se do modo como se experimenta o sentido conforme o enquadramento que cada época lhe dá - o que também 
abre caminho para os esforços, que nos instigam desde o romantismo, de se escrever uma história da arte e da literatura em especial. Mas que história se pode escrever senão tomando apoio na parte degradada do sentido, na parte não-essencial da literatura, que dá à história aquele aspecto de rigidez e de enquadramento forçado que hoje se tende a rejeitar, conforme o demonstra o número crescente de queixas que surgem todos os dias a esse respeito?

Insistamos por mais um pouco na questão. Se a experiência que estamos a chamar aqui de experiência do sentido não se reduz jamais a uma totalidade de interpretação com a qual a consciência pode estar satisfeita, então é possível dizer que as tentativas de reduzi-la desse modo - de convertê-la numa outra coisa que não ela mesma - tendem a se constituir numa espécie de queda, de desvitalização do sentido que, trazendo à luz a interpretação, coloca em debandada alguma coisa de que não se pode prescindir e sem a qual a arte - a literatura em especial - não é arte. A queixa dos poetas é, frequentemente, de que foram subestimados pela crítica ou de que a crítica trabalha contra o espírito, reduzindo a sua amplitude e estreitando os seus horizontes, como se desse estreitamento a poesia saísse prejudicada. Mas o fato é que, apesar do estreitamento, eles continuam a escrever poesia - seus dons de criadores permanecem intactos e sua inspiração inviolada, não obstante os percalços do mundo. Quer-se sempre uma situação favorável? Espera-se da crítica que ela ajude, que ela seja de utilidade num setor com o qual ela pouco ou nada tem a contribuir? Evitemos, porém, avançar nessa direção, para não cometermos a impropriedade de concluir pela total inutilidade da crítica. Ela está aí, de algum modo, e participa do espetáculo, embora seja a partir dela - e não da própria poesia - que surgem as queixas e as insatisfações. Se o sentido que a 
arte tende a constituir, que a arte tende a ser conspira, constantemente, para a sua conversão em interpretação, nada podemos fazer quanto a isso. É próprio do sentido ser assim - uma "inspiração" que suscita palavras não somente no espírito dos poetas, mas também dos leitores -, mas essa situação talvez jamais venhamos a compreendê-la perfeitamente.

Pareceria inadequado supor que existem interpretações que são melhores que as outras. Não está em questão julgar. No entanto podese dizer que há interpretações que são, pelo menos, mais fiéis ao sentido daquilo que querem interpretar - e que essa fidelidade lhes confere um tom de coerência e de equanimidade que, noutras situações, faltaria àqueles que convertem muito depressa o que o sentido lhes diz numa interpretação coerente. Para termos uma ideia, num ensaio contemporâneo sobre Drummond (mais precisamente, sobre um poema de Drummond), um crítico escreveu: "Mas o prosaísmo da lírica moderna não dispensa, de forma alguma, o acento expressivo dos signos. Nesta estrofe, ela se dá com a soma de 'torto', 'sombra', e 'gauche', nomes que intensificam certo modo de ser 'na vida” (VILLAÇA, 2002, p. 24). Diante dessas interpretações, não podemos deixar de perguntar já não tanto por aquilo que as análises revelam, mas pelo que escondem, conforme nos faz pensar a sequencia das palavras do crítico: "Bem examinados, os temos parecem sugerir desvios de uma ordem convencional, antítese desta, cujos correspondentes diretos seriam o iluminado, o direito, o retilíneo - que trazem por analogia os predicados do equilíbrio, da racionalidade, da adaptabilidade”. Encontramos de fato essas conotações no poema? Se as palavras de Blanchot - de que não devemos temer que o comentário 
acrescente ao texto - contêm alguma verdade, então é justo pensar também que o acréscimo pode se manifestar, muitas vezes, como uma privação.

De igual qualidade que o comentário a Drummond seria este, encontrável na mesma revista, sobre um poema de Manuel Bandeira, em que se diz: “O poema 'Balõezinhos' [...] pertencente à obra $\mathrm{O}$ ritmo dissoluto (1924), logo se impõe pelo caráter ao mesmo tempo narrativo e dramático de sua composição. À primeira leitura, somos levados a acompanhar uma cena narrativa condensada a partir da qual o eu lírico passeia o seu olhar pela feira livre de um arrabalde" (TEIXEIRA, 2002, p. 218). As palavras, à primeira vista, parecem justas em relação ao que se pode encontrar no poema, porém à medida que se aprofunda o comentário, a impressão que se tem é de que o acréscimo de palavras apenas esvazia o que se tem a dizer, como se a fidelidade ao sentido que se atribui ao poema exigisse esse esvaziamento para se converter em alguma coisa:

Visto que cênico é o princípio que anima a construção do todo, estamos diante de um modo particularizado de narrar, por via do qual se reforçam os detalhes específicos de espaço, de tempo, de personagem e de ação. Trata-se, portanto, de um procedimento dramático que se combina com uma atitude típica de enunciação lírica (TEIXEIRA, 2002, p. 218).

Dispensamo-nos de multiplicar os exemplos, diante desse esforço que parece buscar muito mais a coerência interna do comentário do que uma real fidelidade ao sentido que o orienta (e os pormenores quanto à verdade desse sentido também nos escapam aqui), se poderia alegar que a qualidade do comentário depende das capacidades pessoais de quem o produz - mas ainda estaríamos no âmbito do 
julgamento. Para efeitos do que estamos a dizer, preferimos pensar que a análise, muito mais do que lançar luz sobre o objeto da leitura, produz um efeito de obnubilação, devido talvez a seus compromissos com a história e a cultura, que não são exatamente compromissos com a verdade da arte - sua verdade paradoxal -, que aceita de bom grado esse acréscimo, ao mesmo tempo em que o desmente e o torna incapaz de pronunciar qualquer verdade:

\begin{abstract}
Deixando de considerar as sugestões cabalísticas do número sete, fiquemos com a pluralidade simples e seu critério de composição. O termo "faces" conduz-nos a rostos e lados, feições e cortes lapidares - expressão humana e angulação geométrica. Enquanto partes, cada uma alude às outras e ao todo resultante delas; mas na particularidade de "faces" resgata-se o que também cada uma, a seu tempo e modo, quer expressar de forma completa. O movimento natural da leitura impõe uma sequência: acidentada embora, uma história subsiste - e é na verdade fundamental enquanto progressão articulada de uma confidência complexa (VILLAÇA, 2002, p. 23).
\end{abstract}

De certo modo, os exemplos (que poderiam se multiplicar ao infinito), mostram que, quando o sentido se converte em interpretação, é como se caísse, e essa queda faz pensar numa verdadeira degradação daquilo que, no entanto, jamais é dito na análise: a sua relação mais profunda com uma verdade que está sempre ameaçada de degradação. Se o sentido se salva, é pelo fato de que se liberta, de que se lança para diante e diz a sua própria verdade, sem que essa verdade deixe de ser, apesar de tudo, uma outra face do silêncio, uma sua dimensão mais profunda e real. E o que é a crítica afinal, senão esse movimento incessante, esse cair incessante do sentido à interpretação, que está sujeito a todos os riscos? No entanto há uma alegria nesse cair, uma vitalidade cujo mistério não está em nossas forças sondar, a qual ignora 
todos os riscos e produz um vasto veio de comentário, sedimentado numa tradição, que se manifesta como a vida de todos os poemas, embora seja também a sua morte. Mas não é a obra aquilo que ela diz, e o seu sentido final não é ela mesma, a cair indefinidamente num universo de palavras que lhe dá acolhida, encontra para ela um lugar e pronuncia o voto da sua eternidade?

Numa das gravuras de Escher, entre tons que vão do cinza escuro ao branco, está representada uma estranha construção em que há uma roda de moinho sobre a qual despenca um veio de água que corre sobre um canal em forma de W. Olhando mais atentamente, descobrimos que o canal, na verdade, é sustentado pela estrutura de duas torres alinhadas em ângulo reto com o fundo da construção, e que os vértices dos dois triângulos que o formam cortam, inexplicavelmente, essas estruturas, isto é, de modo que o movimento da água, partindo da roda à esquerda, caminha para a direita, em direção à torre mais baixa, e "sobe" para a torre mais alta, voltando outra vez para a esquerda até alcançar o ponto à direita de onde despenca novamente para fazer girar a roda do moinho. Ao paradoxo desse movimento, Escher (1994, p. 16) acrescenta o seguinte comentário: "O moleiro tem, de vez em quando, de deitar um balde de água para compensar a perda de evaporação”, completando-o com a observação de que "ambas as torres são da mesma altura, mas a da direita está, contudo, um andar mais baixo do que a da esquerda”. A perspectiva parece correta, e não há como negar que a roda se situa exatamente abaixo da torre à esquerda, embora o movimento que a água faz de correr seja em direção ao fundo, não importando que as torres estejam lado a lado. Se a descrição falha, é porque o quadro a proíbe - e aqui não podemos fazer mais nada senão calar. 
Tal como nos quadros em que uma superfície plana é preenchida totalmente por figuras que se encaixam umas nas outras, sem espaços vazios entre elas, nada na litogravura pode ser tomado como metáfora do mundo e muito menos como dotado de algum sentido mais profundo ou recôndito, porque qualquer sentido que se atribua ao quadro dependerá do que está representado nele, sendo ele, em sua plena visibilidade, o limite da possibilidade e a possibilidade total daquilo que representa. Incorreríamos em erro se pensássemos que ele nos oculta alguma coisa ou que o segredo de seu sortilégio advém do uso equivocado dos recursos de representação da pintura em perspectiva, pois, conforme palavras do próprio Escher, "se seguirmos com os olhos todas as partes desta construção, não se pode descobrir um único erro". E, por certo, não se descobre nenhum erro, mas se pode pelo menos sonhar que exista algum; ou, melhor, que o cair da água que sai de um mesmo ponto e a ele retorna sem parar seja o cair infinito nesse erro do qual, porém, não queremos nos libertar.

Como no universo da crítica, o sentido que vai é o mesmo que volta, e o que cai na interpretação já é imediatamente sentido e novamente interpretação. E, se a crítica quisesse colocar-se na posição do pequeno ocioso que, com os cotovelos apoiados ao peitoril, observa da base o movimento da água, ela não poderia senão imaginar, num devaneio, um mundo em que as coisas fossem diferentes.

\section{Referências}

BLANCHOT, M. A parte do fogo. Tradução de Ana Maria Scherer. Rio de Janeiro: Rocco, 1997. 
EIKHENBAUM, B. A teoria do "método formal”. In: TOLEDO, D. O. (Org.). Teoria da literatura: formalistas russos. Porto Alegre: Globo, 1971.

ESCHER, M. C. Gravura e desenhos. Tradução de Maria Odete Gonçalves-Koller. Colônia: Benedikt Taschen Verlag, 1994.

GULLAR, F. Argumentação contra a morte da arte. Rio de Janeiro: Revan, 1993. JIRMUNSKI, V. Sobre a questão do “método formal”. In: TOLEDO, D. O. (Org.). Teoria da literatura: formalistas russos. Porto Alegre: Globo, 1971.

KAYSER, W. Análise e interpretação da obra literária: introdução à ciência da literatura. 7. ed. Coimbra: Arménio Amado, 1985.

MONTEIRO, A. C. Clareza e mistério da crítica. Rio de Janeiro: Fundo de Cultura, 1961.

TEIXEIRA, C. M. A resistência do olhar: uma leitura do poema "Balõezinhos" de Manuel Bandeira. Teresa: revista de literatura, São Paulo, n. 4, 2002. TYNIANOV, J. A noção de construção. In: TOLEDO, D. O. (Org.). Teoria da literatura: formalistas russos. Porto Alegre: Globo, 1971.

VILLAÇA, Al. Drummond: primeira poesia. Teresa: revista de literatura, São Paulo, n. 4, 2002.

WELLEK, R.; WARREN, A. Teoria da literatura. Tradução de José Palla e Carmo. Lisboa: Publicações Europa-América, 1962.

Recebido em 26/06/2017. Aprovado em 09/10/2017. 